Ю.Ф. Кучеренко ${ }^{1}$, А.М. Носик ${ }^{2}$, С.І. Сімонов ${ }^{1}$, , С.В. Шубін ${ }^{1}$

${ }^{1}$ Харківський національний університет Повітряних Сил ім. І. Кожедуба, Харків

${ }^{2}$ Національний технічний університет “Харківський політехнічний інститут”, Харків

\title{
МЕТОДИКА ОЦІНКИ ЕФЕКТИВНОСТІ НАДІЙНОСТІ ФУНКЦІОНУВАННЯ АВТОМАТИЗОВАНОЇ СИСТЕМИ ВІЙСЬКОВОГО ПРИЗНАЧЕННЯ, ЯК СКЛАДНОЇ ОРГАНІЗАЦІЙНО-ТЕХНІЧНОЇ СИСТЕМИ
}

\begin{abstract}
У статті показано зростання ваги застосування автоматизованих систем військового призначення при веденні сучасних воєнних конфліктів збройними силами, щзо направлене на отримання інформаційної переваги над противником за рахунок використання можливостей єдиного командно-інформаційного простору всіма його користувачами. При застосуванні автоматизованих систем військового призначення як у повсякденній діяльності військ, так і при виконанні ними бойових завдань дуже часто у органів управління $\epsilon$ потреба здійснювати поточну оцінку ефективності їх функиіонування за основними властивостями, в тому числі і за надійністю функиіонування, з метою прийняття ними обгрунтованих рімень щзодо необхідності виконання певних заходів для відновлення їх функціонування або порівняння їх між собою для визначення можливостей з автоматизованого управління підпорядкованими об'єктами управління. Представлена методика оцінки ефективності надійності функціонування автоматизованої системи військового призначення, дає можливість органам управління у стислі терміни, застосовуючи простий математичний апарат, здійснювати поточну оцінку надійності ї̈ функціонування. Головна відмінність даної методики оцінки ефективності надійності функиіонування автоматизованої системи військового призначення від інших полягає в тому, щьо вона дозволяє відповідним органам управління визначити ії ефективність синхронізовано з термінами цииклів управління військами та засобами з врахуванням обраного в неї способу управління об'єктами управління. Даний матеріал доцільно використовувати органам управління при здійсненні поточної оцінки надійності функціонування автоматизованих систем військового призначення для вибору шляхів з виконання необхідних заходів щодо поліпшення ії надійності функиіонування при плануванні застосування відповідних сил та засобів в операції або для здійснення порівняння різних систем між собою за основними їх властивостями.
\end{abstract}

Ключові слова: автоматизована система військового призначення, війська, засоби, ефективність, методика, міжвидове угруповання, надійність, оцінка, органи управління, функиіонування.

\section{Вступ}

Постановка проблеми. Останні воєнні конфлікти, що відбувалися у світі, підтверджують факти широкомасштабного та комплексного застосування збройними силами деяких розвинутих країн світу багатьох видів інформаційних засобів і розвідувально-ударних комплексів, а також різних автоматизованих систем військового призначення (АСВП) 3 метою підвищення ефективності управління своїми міжвидовими угрупованнями військ (МУ) у реальному масштабі часу. Інтегроване застосування інформаційних засобів, комплексів та АСВП дає можливість технологічно розвинутим збройним силам отримати інформаційну перевагу над противником, за рахунок формування та використання можливостей єдиного командно-інформаційного простору (СКІП) в зоні ведення операції (бойових дій) всіма його користувачами починаючи від командирів i органів управління (OУ) різних рівнів управління та закінчуючи солдатом (екіпажем, засобом) на полі бою. Дані обставини дають їм можливість виконувати свої завдання синхронізовано у часі за єдиним задумом командування та у реальному масштабі часу, маючи при цьому глибоку усвідомленість про ситуацію, що склалася в зоні їх відповідальності. Це свідчить про те, що настала епоха ведення мережецентричних війн (МЦВ), при веденні яких відбувається протиборство не тільки МУ військ на полі бою але і різних АСВП у інформаційній сфері. Звідси, дуже часто постає питання щодо проведення ОУ порівняння деяких АСВП між собою, за рахунок здійснення їх оцінки або визначення необхідного переліку заходів, які треба виконати технічному персоналу та ОУ, щоб поліпшити якість їх функціонування, і відповідно до цього, збільшити можливості своїх військ. Здійснення оцінки АСВП за основними іiі властивостями (оперативністю управління, безперервністю управління, прихованістю управління, надійністю функціонування), що характе- 
ризують процес управління підпорядкованими військами та засобами, дуже складне завдання. Оскільки сучасна АСВП уявляє собою складну організаційно-технічну систему, бо забезпечує реалізацію дуже складних процесів 3 управління МУ військ і їх бойовими засобами, а також є багато-ієрархічною та територіально розподіленою системою. Процес іiі функціонування характеризується багатьма властивостями, які в свою чергу визначаються деякими показниками, котрі характеризуються різноманітними просторовими, часовими та імовірнісними характеристиками і все це уявляє собою багаторівневу структуру, що складається із взаємопов'язаної сукупності властивостей, показників та характеристик. Для здійснення оцінки АСВП між собою за основними їх властивостями необхідно витратити багато часу, якого у ОУ, особливо під час ведення бойових дій, не вистачає. Тому застосування ОУ простих методик, які б дозволяли здійснювати своєчасну оцінку функціонування АСВП на основі визначення ефективності основних їх властивостей має дуже актуальне значення.

Аналіз літератури. В наведеній літературі [121] розглядаються питання щодо особливостей сучасних війн [1-7], застосування військ та управління ними $[2 ; 5 ; 7-8]$, розвитку різних систем управління та оцінки ефективності їх функціонування [9-21], але розгляду методики, що дозволяє ОУ здійснити оцінку ефективності надійності функціонування АСВП в стислі терміни та з урахуванням обраного способу управління, в них уваги не приділялось.

Мета статті полягає в розгляді питання щодо здійснення ОУ поточної оцінки ефективності надійності функціонування АСВП, як складної організаційно-технічної системи за даною методикою, що дозволяє зробити це у стислі терміни з врахуванням застосування різних способів управління в системі.

\section{Виклад основного матеріалу}

Під надійністю функціонування АСВП, як однієї з основних іiі властивостей, будемо розуміти здатність системи зберігати технічну надійність іiі комплексів засобів автоматизації (КЗА), як основних елементів іiі технічної основи (структури), якість виконання технічним персоналом (ТП) своїх функціональних обов'язків щодо експлуатації даних КЗА i прийняття ОУ обгрунтованих управлінських рішень, як основних елементів іiї організаційної основи, в межах термінів, що задані, з метою забезпечення збереження необхідних параметрів процесу автоматизованого управління підпорядкованими ій об’єктами управління. Враховуючи те, що КЗА, ТП та ОУ розміщуються на відповідних автоматизованих пунктах управління (АПУ) даної АСВП з метою реалізації загального процесу управління підпорядкованими військами та засобами, процес іiі функціо- нування можливо представити як упорядковану взаємодію сукупності територіально розподілених АПУ різних ланок управління.

Треба зазначити, що загальні вимоги до надійності функціонування АСВП з часом постійно підвищуються у зв'язку із підвищенням вимог щодо синхронізованого застосування усіх вогневих та технічних засобів різних МУ, що приймають участь у сучасних операціях (бойових діях).

Порушення функціонування АСВП можливо за рахунок впливу на неї зовнішніх і внутрішніх факторів, наслідком дії яких $є$ виникнення відмов у апаратурі КЗА або помилок у роботі ОУ чи ТП, що призводить до зниження ефективності надійності функціонування АСВП і в цілому до зниження загальної її ефективності, а в деяких випадках (за рахунок застосування противником засобів вогневого ураження, радіоелектронної боротьби або інформаційного впливу), призводять до неможливості виконання нею своїх завдань.

Розглянемо пропонуєму методику оцінки ефективності надійності функціонування АСВП.

Враховуючи, що функціонування АСВП уявляє собою упорядковану взаємодію певної сукупності територіально розподілених АПУ різних ланок управління, то визначення ефективності надійності

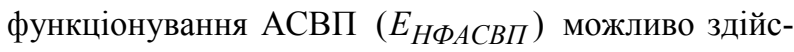
нити через оцінку ефективності показника надійності функціонування сукупності АПУ у відповідних циклах управління військами (засобами) -

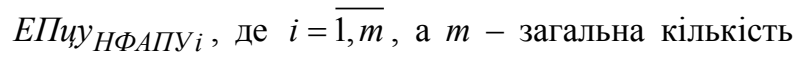
АПУ у відповідному циклі управління (на маршруті передачі управлінських впливів на об'єкти управління при застосуванні відповідного способу управління (централізованого, децентралізованого, мережевого)), визначеним за відповідним критерієм його оцінки Криу НФАПу ${ }_{i}$. Значення даного критерію встановлюється за відповідними оціночними інтервалами, що визначаються експертами на основі застосування методу експертних оцінок.

Оцінку ЕПиу НФАПу $і$ можливо здійснювати за відношенням поточного (реального) значення показника надійності функціонування сукупності АПУ при визначеному способі управління до ідеального (заданого) значення показника надійності функціонування сукупності АПУ при тому ж способі управління, що буде визначатись співвідношенням

$$
E \Pi u y_{H Ф A \Pi y_{i}}=\frac{\Pi u y_{P H Ф A П y_{i}}}{\Pi u y_{I H Ф A \Pi y_{i}}},
$$

де Пиу РНФАПу дійності функціонування сукупності АПУ у відповідних циклах управління, що визначається при застосуванні АСВП в реальних умовах і використанні певного способу управління бойовими засобами (Б3); 
Пиу ІНФАПу $i_{i}$ - ідеальне (задане) значення показника надійності функціонування сукупності АПУ у тих же циклах управління, що задається (встановлюється) в технічній документації на дану систему 3 врахуванням ідеальних умов іiі застосування і використанні того ж способу управління військами (Б3).

Оцінка ЕПиу НФАПу $і$ здійснюється шляхом порівняння отриманого значення зі значенням критерію його оцінки у відповідності до значень визначених оціночних інтервалів, які встановлюються на основі застосування методу експертних оцінок, за наступними правилами:

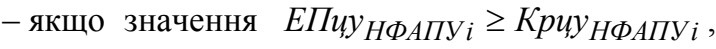
де $K_{\text {puy }}$ "відмінна";

- якщо значення ЕПиу НФАПУ між оціночними інтервалами Криу ${ }_{\text {НФАПУ }}^{1}>$ ЕПй $_{\text {НФАПУ }} \geq$ Кри $^{2}{ }_{\text {НФАПУ }}$, де

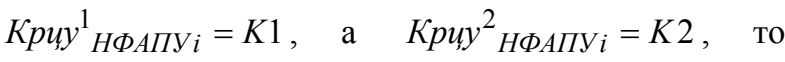

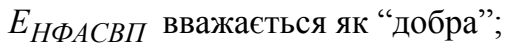

- якщо значення ЕПиу між оціночними інтервалами

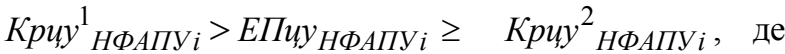
Криу ${ }_{\text {НФАПУ }}^{1}=K 2, \quad$ a Kриу $_{\text {HФАПУ } i}^{2}=K 3, \quad$ то

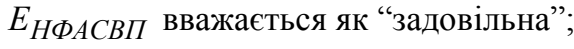

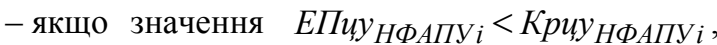

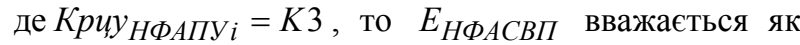
“незадовільна".

Враховуючи вимоги до топологічної структури АСВП в частині організації напрямків передачі інформації між АПУ різних рівнів управління, що визначають наявність незалежних шляхів видачі інформації (по вимогам до іï топологічної структури повинні бути не менш двох незалежних шляхів передачі інформації (основний та резервний), а також той факт, що найдовша ланка управління при централізованому управлінні в $N$ рівневій структурі АСВП складає $N$ АПУ (для прикладу візьмемо АСВП, що має чотирьох рівневу структуру управління, тобто в циклі управління задіяні 4 АПУ), що складає найдовший цикл управління підпорядкованими військами (БЗ).

При застосуванні децентралізованого управління в АСВП, управління об'єктами управління здійснюється по основному та резервному шляху за прямими напрямками зв'язку (в циклі управління задіяні 2 АПУ). Отримуємо високу технічну надійність, але при цьому маємо мінімальне значення обгрунтованості прийняття оптимальних рішень ОУ, оскільки вони не мають відомості про дію інших частин, про стан ситуації та об’єктивну обстановку в зоні ведення бойових дій.

При мережному управлінні в АСВП за рахунок застосування телекомунікаційних вузлів (ТКВ), здійснюється прив'язка кожного АПУ до двох ТКВ, що дозволяє поєднати централізоване і децентралізоване управління та зменшити проміжні рівні (ланки) управління і одночасно підвищити живучість топологічної структури системи за рахунок збільшення маршрутів (шляхів) передачі інформації. В даному випадку управління військами (Б3) в циклі управління здійснюється за допомогою 2 АПУ та ТКВ з будь-якого рівня управління за 6 незалежними маршрутами. При даному управлінні в АСВП ОУ можуть приймати максимально обгрунтовані рішення на АПУ всіх ланках управління і при цьому мати максимальну живучість топологічної структури.

Тоді, при застосуванні в АСВП різних способів управління, можливо очікувати наступні варіанти визначення Пиу РНФАПу ${ }_{i}$ :

- імовірність надійності функціонування мар-

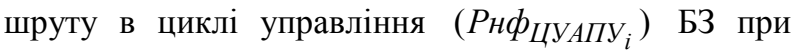
централізованому управлінні, буде визначатись за наступним виразом:

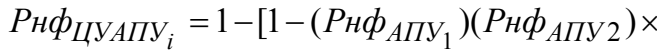

$$
\begin{aligned}
& \left.\times\left(P_{\mu} \phi_{A \Pi \mathrm{V}_{3}}\right)\left(\text { Рнф }_{A \Pi \mathrm{V}_{4}}\right)\right]^{2} ;
\end{aligned}
$$

- імовірність надійності функціонування маршруту в циклі управління Б3 при децентралізованому управлінні $\left(Р н \phi_{\text {ДцУАПу }}\right)$, буде визначатись за наступним виразом:

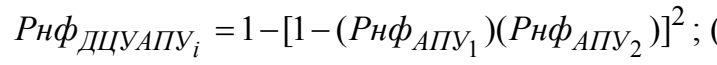

- імовірність надійності функціонування маршруту в циклі управління Б3 при мережному управлінні $\left(\right.$ Рнф$\left.\phi_{\text {МУАПУ }}\right)$, буде визначатись за наступним виразом:

$$
\begin{gathered}
\text { Рнф}_{\text {MУАПУ }_{i}}=1-\left[1-\left(P \mu \phi_{A \Pi y_{1}}\right) \times\right. \\
\left.\times\left(P \mu \phi_{T K B}\right)\left(P H \phi_{A \Pi y_{2}}\right)\right]^{6} .
\end{gathered}
$$

Далі необхідно здійснити визначення показника надійності функціонування всіх АПУ в циклі управління Б3 $\left(\Pi_{Н Ф А П Y_{i}}\right)$, який має комплексний вид і буде визначатись:

- показником технічної надійності його КЗА $\left(\Pi_{T H K 3 A_{i}}\right)$;

- показником надійності роботи його ОУ $\left(\Pi_{\text {HPOУ }_{i}}\right)$ та показником надійності роботи його ТП $\left(\Pi_{\text {HРTП }_{i}}\right)$.

Визначення показника технічної надійності КЗА здійснюється через характеристику технічної надійності певного КЗА $\left(X_{T H \kappa 3 A_{i}}\right)$, а саме через 
коефіцієнт заданої $\left(\right.$ Коф $\left.{ }_{Г з К з A_{i}}\right)$ або реальної його готовності $\left(\right.$ Коф $\left.\phi_{Г Р К з A_{i}}\right)$.

Заданий коефіцієнт готовності КЗА є основним показником його технічної надійності, який означає вірогідність того; що КЗА буде знаходитись в працездатному стані у довільний момент часу і встановлюється технічною документацією на відповідний K3A.

Визначення значення $\operatorname{Koф}_{Г Р К З A_{i}}$, рахується як співвідношення часу, протягом якого КЗА знаходився у працездатному стані, до загальної тривалості розглянутого періоду спостережень, за виразом

$$
\operatorname{Koф}_{\Gamma Р К 3 A_{i}}=\frac{\sum_{i=1}^{m} \Delta t_{i}}{T_{C \Pi}},
$$

де $\Delta t_{i}$ - тривалість $i$-го інтервалу часу безупинного функціонування КЗА;

$T_{C \Pi}$ - загальна тривалість періоду спостереження за роботою КЗА (загальна тривалість операціiі);

$m$ - загальна кількість інтервалів часу безупинного функціонування КЗА за період спостереження, $i=\overline{1, m}$. Значення величини даного коефіцієнту знаходиться в інтервалі чисел $[0 ; 1]$.

Далі здійснимо визначення показника надійності роботи його ОУ $\left(\Pi_{\text {НОOУ }_{i}}\right)$ через відповідні характеристики, що його утворюють, а саме: характеристику, що визначає рівень чисельності ОУ $\left(X_{P \text { YOУ }_{i}}\right)$, яка визначається коефіцієнтом рівня чисельності ОУ (Коф РчОУАПу $\left._{i}\right)$; характеристику, що визначає рівень фахової підготовки ОУ $\left(X_{\text {РФПоу }}\right)$, яка визначається коефіцієнтом рівня фахової підготовки ОУ (КофРФПоУАПу $\left.{ }_{i}\right)$.

$\kappa_{\text {КофоУАПУ }}$ визначається як відношення наявної чисельності ОУ даного АПУ $\left(\mathrm{Hu}_{\mathrm{O}_{\text {OАПУ }}}\right)$ до його визначеної штатної чисельності ОУ $\left(\right.$ Шч $\left.{ }_{\text {OуАПУ }}\right)$, за виразом

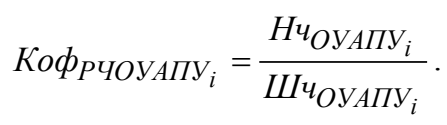

Даний коефіцієнт через встановлення значення відповідного рівня наявної чисельності ОУ даного АПУ характеризує можливості щодо своєчасного виконання даним складом ОУ певних дій (щодо організації процесу управління військами, взаємодії з ОУ інших АПУ, відповідних алгоритмів їх дій за різними ситуаціями, контролю та виконання заходів 3 управління підпорядкованими об'єктами управління та інше) загального процесу управління військами (засобами), що будуть впливати на відповідні часові значення реальних термінів циклів управління підпорядкованими об'єктами управління. Значення величини Коф валі чисел [0; 1].

Коф $_{\text {РФПоуАПу }}$ визначається як відношення суми балів отриманих наявним складом ОУ даного АПУ за результатами виконання ними завдань 3 професійної підготовки, що оцінюються за п’ятибальною шкалою оцінки їх вмінь та навичок, до загальної максимально можливої суми в балах ("відмінно"-5 балів), які можуть бути отримані всіма ОУ згідно їх штатної чисельності, за виразом

$$
K_{\text {РФПОУАПу }_{i}}=\frac{\sum_{i}^{k} Б_{j} O y_{i}}{5 N},
$$

де $i=\overline{1, k}, k$ - наявна кількість ОУ на даному АПУ;

$b_{j}-$ значення в балах, що отримано кожною особою ОУ, $j=(2,3,4,5)$;

$N$ - загальна штатна чисельність ОУ на даному АПУ;

5 - максимальне значення балу, яке може бути отримано кожною особою ОУ визначеної загальної штатної чисельності на даному АПУ.

Даний коефіцієнт характеризує можливості ОУ щодо обгрунтованого прийняття ними управлінських рішень (якісної оцінки обстановки в зоні відповідальності, прогнозу розвитку ситуації та дій противника в операції, підготовки та прийняття оптимального рішення на застосування відповідних сил i засобів та таке інше) на основі оцінки їх фахової підготовки. Значення величини Коф РФПоуАПу знаходиться в інтервалі чисел $[0 ; 1]$.

Загальний показник надійності роботи ОУ певного АПУ $\left(\Pi_{\text {НРОУАПУ }}\right)$ визначається через добу-

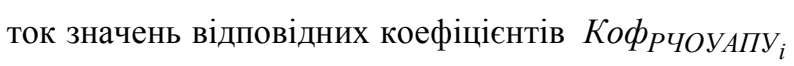

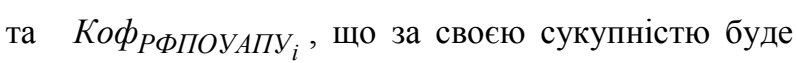
характеризувати реальну готовність ОУ виконувати свої обов'язки (Коф підпорядкованими силами і засобами та означатиме імовірність того, що ОУ спроможні виконати свої обов'язки у певний момент часу. Тоді враховуючи вирази 6, 7 даний коефіцієнт можливо визначити за виразом

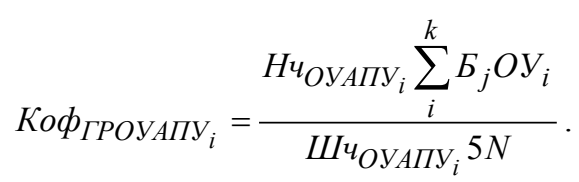

Далі продовжимо визначення показника надійності роботи ТП (Птглг.) через відповідні характеристики, що його утворюють, а саме: характеристику, що визначає рівень чисельності ТП ( $\left.X_{\text {пгтг }}\right)$ 
яка визначається коефіцієнтом рівня чисельності ТП $\left(\right.$ Коф $\left._{\text {РчТПАПу }}\right)$; характеристику, що визначає рі-

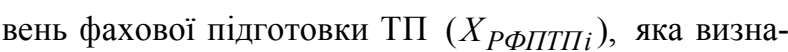
чається коефіцієнтом рівня фахової підготовки ТП $\left(\kappa о \phi_{\text {РФПтПАПУ }}\right)$. Дані коефіцієнти визначаються аналогічно як і для ОУ (вирази 6-8), що було вище наведено, а їх значення знаходяться в інтервалі чисел $[0 ; 1]$.

Загальний показник надійності роботи ТП пев-

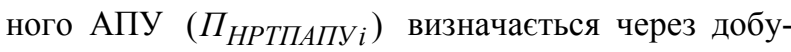
ток значень відповідних коефіцієнтів $\kappa_{\text {Коф }}{ }_{\text {РТПАПУ } i}$ та Коф РФПТПАПУ $i$, що за своєю сукупністю буде характеризувати реальну готовність ТП виконувати свої обов'язки щодо експлуатації КЗА АСВП та означатиме імовірність того, що ТП спроможний виконати свої обов'язки у певний мо-

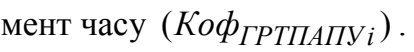

Вирахувавши Коф та Коф дійності функціонування будь якого АПУ АСВП

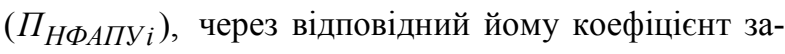

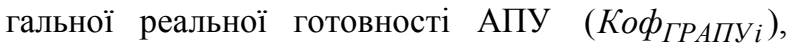
який буде визначатись як добуток реальних значень вказаних коефіцієнтів за наступним виразом

$$
\begin{aligned}
& \operatorname{Koф~}_{\text {ГРАПУ }}=\operatorname{Koф}_{\text {ГРКЗААПУ }} \times \\
& \times \text { Коф }_{\text {ГРОУАПУ }} \text { Коф }_{\text {ГРТПАПУ }} .
\end{aligned}
$$

Даний коефіцієнт показує імовірність виконання певним АПУ завдань 3 реалізації процесу управління підпорядкованими військами (засобами) в реальних умовах обстановки.

Після визначення коефіцієнтів реальної готовності всіх АПУ АСВП, можливо здійснити визначення показника реальної надійності функціонування АСВП, як сукупності АПУ у відповідних циклах управління військами (засобами) - Пиу РНФАПу ${ }_{i}$, де $i=\overline{1, n}$, а $n$ - загальна кількість АПУ у циклі управління через відповідні коефіцієнти реальної готов-

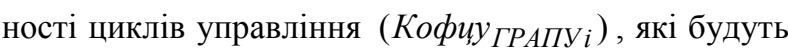
визначатись в залежності від обраного способу управління в АСВП згідно виразів: при централізова- ному управлінні згідно виразу 2; при децентралізованому управлінні - виразу 3; при мережевому управлінні - виразу 4.

Даний коефіцієнт показує імовірність реальної надійності функціонування АСВП, в реальних умовах іiі застосування, за відповідними циклами управління при управлінні підпорядкованими військами (засобами) при застосуванні в системі певного способу управління. Значення Кофиу ГзАПуі - буде визначати імовірність заданої (ідеальної) надійності функціонування АСВП за ідеальних умов іiї застосування, за відповідними циклами управління силами (засобами) і при застосуванні аналогічного способу управління.

Тоді оцінку ефективності надійності функціо-

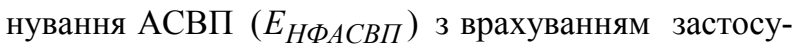
вання різних способів управління в систем за відповідними циклами управління можливо здійснювати за наступним виразом:

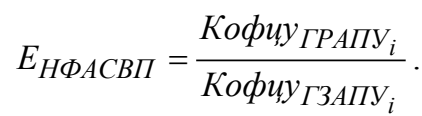

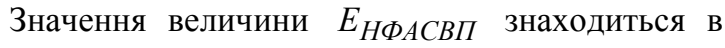
інтервалі чисел $[0 ; 1]$.

\section{Висновки}

Оцінка ефективності надійності функціонування автоматизованих систем військового призначення, що здійснюється за допомогою розглянутої методики дає можливість органам управління швидко та зручно здійснювати ії визначення синхронізовано 3 термінами циклів управління військами та засобами 3 врахуванням обраного в автоматизованих системах військового призначення способу управління об'єктами управління. Даний матеріал доцільно використовувати органам управління при здійсненні поточної оцінки надійності функціонування автоматизованих систем військового призначення для вибору шляхів щодо виконання необхідних заходів 3 поліпшення іï надійності функціонування або для здійснення порівняння різних автоматизованих систем військового призначення між собою за основними їх властивостями.

\section{Список літератури}

1. Владимиров А.И. Основы общей теории войны: монография / А.И. Владимиров. - М.: Синергия, 2013. - 832 с.

2. Сидорин А.Н. Вооруженные силы США в ХХІ веке: Военно-теоретический труд / А.Н. Сидорин, В.М. Прищепов, В.П. Акуленко. - М.: Кучково поле, 2013. - 800 с.

3. Кушнір O.І. Аналіз впливу “гібридної” війни на розвиток автоматизованої системи управління авіацією та ППО Збройних Сил України / О.І. Кушнір, О.П. Давикоза, Ю.Ф. Кучеренко // Наука і техніка Повітряних Сил Збройних Сил України. - 2017. - № 2(27). - С. 116-120.

4. Савин Л.В. Сетецентрическая и сетевая война. Введение в концепцию / Л.В. Савин. - М.: Евразийское движение, 2011. $-130 \mathrm{c}$.

5. Кучеренко Ю.Ф. Погляди щодо напрямів розвитку тактики дій формувань тактичного рівня при їх застосуванні в сучасних операціях (війнах) / Ю.Ф. Кучеренко, А.М. Носик // Наука і техніка Повітряних Сил Збройних Сил України. 2015. - № 2(19). - C. 24-26. 
6. Паршин С.А. Кибервойны - реальная угроза национальной безопасности? / С.А. Паршин, Ю.Е. Горбачев, Ю.А. Кожанов. - М.: КРАСАНД, 2011. - 96 с.

7. Информационные, специальные, воздушно-десантные и аэромобильные операции армий ведущих зарубежных государств / А.Н. Сидорин, И.А. Рябченко, В.П. Герасимов и др. - М.: Воениздат, 2011. - 344 с.

8. Основы теории применения управления в системах специального назначения / Ю.В. Бородакий, А.В. Боговик, В.И. Курносов и др.; под общ. ред. Ю.В. Бородакия, В.В. Масановца. - М.: Управление делами президента РФ, 2008. $400 \mathrm{c}$.

9. Демідов Б.О. Концептуальні положення щодо створення автоматизованої системи управління протиповітряною обороною держави / Б.О. Демідов, О.Ф. Величко, Ю.Ф. Кучеренко // Наука і оборона. - 2014. - № 3. - С. 51-56.

10. Искусственный интеллект и интеллектуальные системы управления / И.М. Макаров, В.М. Лохин, С.В. Манько, М.П. Романов. - М.: Наука, 2006. - 333 с.

11. Московитов Н. Перспективы создания глобальной информационной сети МО США / Н. Московитов, Г. Рыбаков // Зарубежное военное обозрение. - 2013. - № 7. - С. 8-19.

12. Управління проектами зі створення зразків озброєння та військової техніки в умовах прояву факторів невизначеності та ризику / Б.О. Демідов, О.Ф. Величко, Ю.Ф. Кучеренко, М.В. Куцак // Озброєння та військова техніка. - 2016. № 2(10). - С. 15-19.

13. Кучеренко Ю.Ф. Метод оцінювання ефективності автоматизованої системи військового призначення за станом іiї складових основ / Ю.Ф. Кучеренко, В.М. Гордієнко, Ю.С. Литвинов // Системи управління, навігації та зв'язку. - 2012. - № 2(22). - С. 141-143.

14. Кучеренко Ю.Ф. Оцінка ефективності автоматизованих систем управління міжвидових угруповань військ / Ю.Ф. Кучеренко // Наука і техніка Повітряних Сил Збройних Сил України. - 2013. - № 2(11). - С. 49-51.

15. Кучеренко Ю.Ф. Методика оцінки загального стану автоматизованої системи військового призначення на основі визначення технічного стану комплексів засобів автоматизації, що ії̈ складають / Ю.Ф. Кучеренко // Системи обробки інформації. - 2017. - № 3(149). - С. 118-120.

16. Ярош С.П. Теоретичні основи побудови та застосування розвідувально-управляючих інформаційних систем протиповітряної оборони / С.П. Ярош. - Х.: ХУПС, 2012. - 512 с.

17. Кучеренко Ю.Ф. Методологічні аспекти проектування матеріально-технічної основи автоматизованої системи військового призначення / Ю.Ф. Кучеренко // Системи озброєння і військова техніка. - 2018. - № 2(54). - С. 94-98.

18. Ковалевський С.М. Пропозиції щодо створення скритого маловисотного радіолокаційного поля в умовах ведення сучасних мережецентричних та гібридних війн / С.М. Ковалевський, Г.В. Пєвцов, Г.В. Худов // Наука і техніка Повітряних Сил Збройних Сил України. - 2015. - № 1(18). - С. 77-81.

19. Васильев В.И. Интеллектуальные системы управления. Теория и практика / В.И. Васильев, Б.Г. Ильясов. - М.: Радиоэлектроника, 2009. - 392с.

20. Куприянов А.И. Радиоэлектронные системы в информационном конфликте / А.И. Куприянов, А.В. Сахаров. М.: Вузовская книга, 2003. - 528 с.

21. Худов Г.В. Методика синтезу раціональної структури підсистеми розвідки системи протиповітряної оборони 3 використанням генетичного алгоритму / Г.В. Худов, І.А. Таран // Наука і техніка Повітряних Сил Збройних Сил України. -2016 . - № 2(23). - С. 25-31.

Надійшла до редколегії 01.07.2020

Схвалена до друку 18.08.2020

\section{Відомості про авторів:}

\section{Кучеренко Юрій Федорович}

кандидат технічних наук провідний науковий співробітник

Харківського національного

університету Повітряних Сил ім. І. Кожедуба,

Харків, Україна

https://orcid.org/0000-0001-9937-371X

\section{Носик Андрій Михайлович}

кандидат технічних наук старший науковий співробітник доцент Національного технічного університету

“Харківський Політехнічний Інститут",

Харків, Україна

https://orcid.org/0000-0002-4171-1875

\section{Сімонов Сергій Іванович}

науковий співробітник

Харківського національного університету

Повітряних Сил ім. І. Кожедуба,

Харків, Україна

https://orcid.org/0000-0001-9417-9256
Information about the authors:

\section{Yurii Kucherenko}

Candidate of Technical Sciences Lead Research of Ivan Kozhedub Kharkiv National

Air Force University,

Kharkiv, Ukraine

https://orcid.org/0000-0001-9937-371X

\section{Andrii Nosyk}

Candidate of Technical Sciences Senior Research

Associate Professor of National Technical University

"Kharkiv Polytechnic Institute",

Kharkiv, Ukraine

https://orcid.org/0000-0002-4171-1875

\section{Sergey Simonov}

Research Associate

of Ivan Kozhedub Kharkiv National

Air Force University,

Kharkiv, Ukraine

https://orcid.org/0000-0001-9417-9256 
Шубін Свген Вікторович

кандидат технічних наук

старший науковий співробітник

старший науковий співробітник

Харківського національного університету

Повітряних Сил ім. І. Кожедуба,

Харків, Україна

https://orcid.org/0000-0002-3411-8125
Yevhen Shubin

Candidate of Technical Sciences

Senior Research

Senior Research Associate

of Ivan Kozhedub Kharkiv National

Air Force University,

Kharkiv, Ukraine

https://orcid.org/0000-0002-3411-8125

\title{
МЕТОДИКА ОЦЕНКИ ЭФФЕКТИВНОСТИ НАДЕЖНОСТИ ФУНКЦИОНИРОВАНИЯ АВТОМАТИЗИРОВАННОЙ СИСТЕМЫ ВОЕННОГО НАЗНАЧЕНИЯ, КАК СЛОЖНОЙ ОРГАНИЗАЦИОННО-ТЕХНИЧЕСКОЙ СИСТЕМЫ
}

Ю.Ф. Кучеренко, А.М. Носик, С.И. Симонов, Е.В. Шубин

В статье показано возрастание роли применения автоматизированных систем военного назначения при ведении современных военных конфликтов вооруженными силами ведущих стран мира, которое направлено на получение информационного преимущества над противником за счет использования возможностей единой командноинформационной среды всеми ее пользователями. Представленная методика оценки эффективности надежности функционирования автоматизированной системы военного назначения, дает возможность органам управления в сжатые сроки, применяя простой математический аппарат, осуществлять текущую оценку надежности ее функиионирования. Данный материал целесообразно использовать органам управления при осуществлении текущей оценки надежности функционирования автоматизированных систем военного назначения для выбора путей для выполнения мероприятий по улучшению ее надежности функционирования или для осуществления сравнения разных систем между собой за основными их свойствами.

Ключевые слова: автоматизированная система военного назначения, войска, средства, эффективность, методика, межвидовая группировка, надежность, оценка, органы управления, функционирование.

\section{METHODOLOGY FOR ESTIMATING EFFICIENCY OF RELIABILITY OF FUNCTIONING OF AUTOMATED MILITARY SYSTEM, AS COMPLEX ORGANIZATIONAL-TECHNICAL SYSTEM}

\author{
Yu. Kucherenko, A. Nosyk, S. Simonov, Ye. Shubin
}

The article discusses the increasing role of the use of automated military systems in the conduct of modern military conflicts by the armed forces of the leading countries of the world, which is aimed at gaining an information advantage over the enemy by using the capabilities of a single command and information environment by all its users. The presented methodology for assessing the effectiveness of the reliability of the operation of an automated military system allows control bodies to use a simple mathematical apparatus to carry out a current assessment of the reliability of its operation in a short time. The main difference between this methodology for assessing the effectiveness of the reliability of the operation of an automated military system from others is that it allows the appropriate command and control bodies to determine its effectiveness synchronized with the timing of the command and control cycles taking into account the control method chosen in this system. The main difference between this methodology for assessing the effectiveness of the reliability of the functioning of an automated military system from others is that it allows the relevant command and control bodies to determine its effectiveness synchronized with the timing of command and control cycles, taking into account the method of control of command and control objects chosen in it. It is advisable to use this material for management bodies in the ongoing assessment of the reliability of the operation of automated military systems for choosing ways to take measures to improve its reliability and to compare different systems with each other for their main properties .

Keywords: military-automated system, troops, means, efficiency, methodology, interspecific grouping, reliability, assessment, governing bodies, functioning. 